\title{
PENDAPATAN KELUARGA PETANI DARI BETERNAK KAMBING DI KECAMATAN RASAU JAYA KABUPATEN KUBU RAYA KALIMANTAN BARAT
}

\author{
${ }^{1)}$ Josua Parulian Hutajulu dan ${ }^{2)}$ Yuli Arif Tribudi \\ 1. Program Studi Agribisnis, Fakultas Pertanian Universitas Tanjungpura Pontianak \\ 2. Program Studi Peternakan, Fakultas Pertanian Universitas Tanjungpura Pontianak
}

Correspondence author : josuaparulianhutajulu00@gmail.com

\begin{abstract}
ABSTRAK
Penelitian ini bertujuan untuk mengetahu kontribusi usaha ternak kambing terhadap pendapatan keluarga petani peternak. Penelitian ini dilaksanakan di Kecamatan Rasau Jaya Kabupaten Kubu Raya. Penelitian ini dimulai dari bulan Desember 2019. Metode penelitian yang digunakan adalah metode survey dengan penentuan sampel secara purposive sampling dengan jumlah sampel sebanyak 43 peternak. Data yang dikumpulkan adalah data primer dan sekunder. Rata-rata pendapatan usaha ternak kambing adalah Rp 5.464.427,71/tahun pada skala I, Rp 7.955.250,21/tahun pada skala II dan Rp 9.399.334,27/tahun pada skala III. Kontribusi pendapatan usaha ternak kambing terhadap pendapatan keluarga petani peternak di ketiga skala masingmasing adalah $32,8 \%$ pada skala I, $43,6 \%$ pada skala II dan $48,9 \%$ pada skala III yang menggambarkan bahwa usaha ternak kambing di Kecamatan Rasau Jaya masih termasuk tipologi cabang usaha
\end{abstract}

Kata kunci : konstribusi, peternakan kambing dan pendapatan

\begin{abstract}
The aim of this research to analyze how much of goat husbandry activity contribution to the farmers family income. This study was designed using descriptive analysis method by interviewing the respondents directly to obtain the primary data. The secondary data was obtained from village data and BPS. The respondents divide to three scales based on the ownership number of goats among one year ago, such as scale I, scale II and scale III. The annually average income

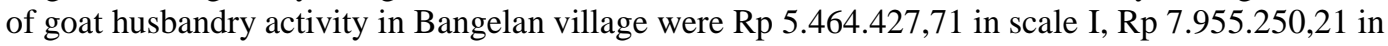
scale II and $\mathrm{Rp} 9.399 .334,27$ in scale III. The annually average income of the farmers family in Kecamatan Cikajang were Rp 17.550.142,71 in scale I, Rp 20.715.250,21 in scale II and Rp 21.699.334,27 in scale III. The annually average contribution of goat husbandry activity to the farmers family income were $32,8 \%$ in scale I, $43,6 \%$ in scale II and $48,9 \%$ in scale III
\end{abstract}

Keywords: contribution; goat husbandry activity and income

\section{Pendahuluan}

Ternak kambing merupakan salah satu jenis ternak yang cukup digemari masyarakat, namun skala usahanya masih bersifat usaha kecil-kecilan di mana sistem pemeliharaan dan perkembangbiakannya masih secara tradisional. Pemeliharaan kambing pada umumnya sebagai usaha sambilan bagi masyarakat peternak, meskipun ada juga yang menjadikan sebagai mata pencaharian pokok. Ternak kambing merupakan salah satu jenis ternak yang mempunyai prospek untuk dikembangkan karena hanya memerlukan sarana dan sistem pemeliharaan yang relatif sederhana serta dapat beradaptasi dengan lingkungan dan jenis pakan (Garantjang, 2004). 
Pola pemeliharaan ternak kambing di Kabupaten Malang sampai saat ini masih didominasi peternakan rakyat dengan cara pemeliharaan yang tradisional. Cara pemeliharaan yang tradisional membutuhkan keterampilan sederhana, menggunakan teknologi tradisional yang turun-temurun, menggunakan bibit lokal dalam jumlah dan mutu yang relatif terbatas, serta tenaga kerja berasal dari keluarga peternak itu sendiri.

Salah satu daerah penghasil ternak kambing di Kalimantan Barat dalah Kecamatan Rasau Jaya Kabupaten Kubu Raya. Ternak kambing bagi masyarakat Rasau Jaya dimulai pada sekitar tahun 1970an sejalan dengan diadakannya program transmigrasi oleh pemerintah Indonesai. Pada tahun 1980 an terdapat program program pemerintah untuk mengembangkan usaha peternakan rakyat dengan mendatangkan kambing Kacang untuk meningkatkan pendapatan petani. Usaha ternak kambing merupakan salah satu jenis usaha yang dapat mendukung pola usaha tani di pedesaan karena dapat memberikan pupuk kandang dan sebagai sumber keuangan untuk membeli kebutuhan pertanian atau untuk memenuhi kebutuhan rumah tangga yang mendadak. Usaha ternak kambing juga sangat disenangi oleh petani peternak di pedesaan karena pemeliharaannya relatif mudah serta tidak memerlukan modal usaha yang besar. Oleh karena itu perlu dilakukan penelitian mengenai karakteristik peternak kambing Kacang di Kecamatan Rasau Jaya Kabupaten Kubu Raya.

\section{Materi dan Metode}

Penelitian dilakukan pada Desember 2018 di Kecamatan Rasau Jaya Kabupaten Kubu Raya. Metode yang digunakan dalam penelitian ini adalah survei. Survei meliputi pengisian kuesioner, untuk informasi secara tertulis dari responden (peternak kambing Kacang berkaitan dengan tujuan penelitian, observasi untuk mengetahui kondisi dan situasi pada sentra peternakan dan interview untuk mencari data yang belum terjawab dalam angket atau jawaban yang masih diragukan. Jumlah peternak yang menjadi responden sebanyak 43 orang peternak.

Data yang diperoleh dianalisis secara deskriptif. Analisis digunakan untuk mengkaji peternak seperti kondisi umum lokasi penelitian, kepemilikan ternak, karakteristik peternak dan tata laksana peternakan serta perkembangan populasi kambing Kacang. Kontribusi pendapatan usahaternak kambing terhadap pendapatan rumah tangga peternak dapat dihitung dengan menggunakan persamaan :

$$
\mathrm{KP}=\frac{\mathrm{X}}{\mathrm{Y}} \times 100 \%
$$


Keterangan :

$\mathrm{KP}=$ kontribusi pendapatan usahaternak kambing terhadap pendapatan rumah tangga peternak $(\%)$

$\mathrm{X}=$ pendapatan bersih usahaternak kambing ( $\mathrm{Rp} /$ peternak/tahun), dan

$\mathrm{Y} \quad=$ pendapatan rumah tangga peternak $(\mathrm{Rp} /$ peternak/tahun $)$

\section{Hasil Dan Pembahasan}

\section{Karakteristik Peternak}

Kecamatan Rasau Jaya pada awalnya bernama Kecamatan Sungai Kakap dan termasuk dalam wilayah Kabupaten Pontianak. Tahun 2001 berubah menjadi Kecamatan Rasau Jaya, Kabupaten Pontianak.Kecamatan Rasau Jaya pada tanggal 17 Agustus 2007 awal dalam wilayah Kabupaten Kubu Raya.Kabupaten Kubu Raya merupakan kabupaten pemekaran dari Kabupaten Pontianak sebagai kabupaten induk dan Kubu Raya sebagai kabupaten pemekaran.

Secara administrasi Kabupaten Kubu Raya meliputi 9 Kecamatan, 106 Desa dan 401 Dusun. Salah satunya adalah Kecamatan Rasau Jaya yang masuk dalam wilayah Kabupaten Kubu Raya. Luas wilayah Kecamatan Rasau Jaya ini merupakan wilayah yang terkecil dari wilayah kecamatan lainnya yaitu sebesar 111,07 $\mathrm{Km} 2$ atau sekitar 1,59\% dari total wilayah Kabupaten Kubu Raya. Kecamatan Rasau Jaya ini terletak di sebelah tenggara Kota Pontianak (Ibukota Provinsi Kalimantan Barat) dan dapat dicapai dengan menggunakan transportasi darat dan sungai

Ternak kambing yang dimiliki oleh peternak responden, berdasarkan umur, terdiri dari kambing anak (jantan/betina) berumur antara 0-6 bulan, kambing muda (jantan/betina) berumur antara 7-12 bulan dan kambing dewasa (jantan/betina) berumur lebih dari 12 bulan. Berdasarkan jumlah ternak kambing yang dimiliki setahun yang lalu, responden dibagi kedalam 3 skala, yaitu skala I, skala II dan skala III. Distribusi responden berdasarkan skala kepemilikan ternak kambing dapat dilihat pada Tabel 1 .

Tabel 1 . Jumlah ternak dan Skala usaha peternakan di lokasi penelitian

\begin{tabular}{ccc}
\hline Jumlah ternak & Skala & Jumlah Responden \\
\hline $2-6$ ekor & I & 23 \\
$7-11$ ekor & II & 15 \\
$12-16$ ekor & III & 5 \\
\hline Jumlah & & $\mathbf{4 3}$ \\
\hline
\end{tabular}

Sistem pemeliharaan kambing di Kecamatan Rasau Jaya rata-rata sudah dilakukan secara semiintensif untuk mempermudah peternak dalam penanganan dan pengawasan terhadap kambing. Dalam satu kandang dimana pejantan, induk dan anak ditempatkan bersama sama. Sistem pemeliharaan tersebut tampaknya berbeda dengan hasil penelitian Chamdi (2002) melaporkan bahwa sistem pemeliharaan ternak kambing di Kecamatan 
Gumelar Kabupaten Banyumas masih sangat tradisional dengan teknologi sederhana secara lemprakan. Martawidjaya (1992) mengemukakan bahwa sebaiknya kandang ternak kambing secara individual sehingga memudahkan untuk membersihkan. Data karasteristik peternak kambing Kacang di Kecamatan Rasau Jaya disajikan pada Tabel 2.

Tabel 2. Karakteristik Peternak Kambing Kacang di Kecamatan Rasau Jaya

\begin{tabular}{lc}
\hline Variabel & Karakteristik Peternak \\
\hline Umur Peternak (tahun) & $51,10 \pm 7,62$ \\
Pendidikan (orang) & 28 \\
- SD & 10 \\
- SMP & 3 \\
- SMA & $4,21 \pm 0,87$ \\
Jumlah Orang dalam Keluarga (orang) & $25,83 \pm 3,12$ \\
Pengalaman Memelihara Kambing (tahun) & $7,73 \pm 2,51$ \\
Jumlah Ternak Yang Dipelihara (ekor) & \multicolumn{2}{c}{ Pengalaman peternak kambing Kacang di Kecamatan Rasau Jaya adalah }
\end{tabular}

25,83 $\pm 3,12$ tahun dimana dilaporkan oleh Rusdiana dan Praharani (2009) bahwa peternak dengan pengalaman beternak yang lebih lama cenderung memiliki ternak yang lebih banyak karena pengalaman memberikan rasa percaya diri yang tinggi kepada peternak untuk berusaha. Pengalaman yang diperoleh seseorang akan memberikan pengaruh terhadap perilaku yang meliputi pengetahuan, ketrampilan dan sikap. Pengalaman akan mempengaruhi pemahaman peternak didalam upaya menunjang manajemen usaha ternaknya.

Kegiatan usaha ternak kambing di Kecamatan Rasau Jaya kebanyakan dikerjakan oleh tenaga kerja keluarga, sehingga anggota keluarga merupakan sumber tenaga kerja yang tersedia untuk kegiatan ternak kambing. Soetriono (2003) menjelaskan bahwa biasanya usaha peternakan dengan skala kecil akan menggunakan tenaga kerja dalam keluarga dan tidak perlu tenaga dari luar, karena dalam kegiatan usahanya dilakukan oleh anggota keluarga itu sendiri. Jenis kegiatan yang dilakukan tenaga kerja keluarga dalam usaha kambing dibagi dalam 8 kelompok, yaitu kegiatan mencari pakan, memberi pakan, membersihkan kandang, memandikan kambing, merawat cempe, mencampur pakan, membawa pakan ke kandang, dan memberi minum. Peternak biasanya mencari pakan untuk kebutuhan dalam sehari dapat dilakukan di lahannya sendiri yang berada dilereng bukit sehingga memerlukan waktu yang lama.

Berdasarkan Tabel 2 dapat diketahui bahwa tingkat pendidikan peternak di Ampelgading adalah bervariasi, rata-rata pendidikan adalah SD. Peternak dengan pendidikan rendah akan lebih sulit dalam menerima informasi mengenai ilmu dan teknologi dalam bidang peternakan. Budiarsana dkk (2001) menyatakan bahwa kemampuan kerja seseorang dipengaruhi oleh umur, pendidikan, dan pengalaman. Ternak 
dengan mutu genetik yang baik akan dapat bereproduksi dengan baik apabila peternak memiliki kualitas SDM yang baik. Pendidikan merupakan sarana untuk meningkatkan kualitas yang dimiliki oleh peternak. Peranan pendidikan didaerah pedesaan terutama adalah untuk mengurangi pengaruh dari kepercayaan dan tradisi yang menghambat pembangunan. Pendidikan menanamkan tata nilai baru yang akan merubah perilaku penduduk untuk bergerak kearah kemajuan. Tingkat pendidikan, pengetahuan dan ketrampilan yang tinggi dapat meningkatkan kesejahteraan peternak.

\section{Kontribusi Pendapatan Usaha Ternak Kambing terhadap Pendapatan Keluarga Petani Peternak}

Kontribusi pendapatan usaha ternak kambing terhadap pendapatan keluarga petani peternak merupakan perbandingan antara pendapatan dari usaha ternak kambing dengan pendapatan peternak. Besarnya kontribusi pendapatan usaha ternak kambing terhadap pendapatan peternak dapat dilihat pada Tabel 3.

Tabel 3. Kontribusi Pendapatan Usaha Ternak Kambing terhadap Pendapatan Keluarga Petani Peternak per Tahun

\begin{tabular}{cccc}
\hline Skala & $\begin{array}{c}\text { Pendapatan Usaha } \\
\text { Ternak Kambing } \\
\text { (Rp/Tahun) }\end{array}$ & $\begin{array}{c}\text { Pendapatan Keluarga Petani } \\
\text { Peternak(Rp/Tahun) }\end{array}$ & $\begin{array}{c}\text { Kontribusi } \\
(\boldsymbol{\%})\end{array}$ \\
\hline I & 6.500 .350 & 20.700 .008 & 31,4 \\
II & 8.634 .210 & 23.530 .150 & 36,7 \\
III & 10.840 .150 & 27.140 .050 & 39,9 \\
\hline
\end{tabular}

Pendapatan peternak skala III lebih besar dari para peternak skala lainnya dimanasemakin besar skala kepemilikan kambing dan penjualan ternak yang dimiliki maka semakin besar pendapatan yang diperoleh peternak kambing di Kecamatan Rasau jaya.. Rata-rata pendapatan usaha ternak kambing adalah Rp 6.500.350/tahun pada skala I, Rp 8.634.210/tahun pada skala II dan Rp 10.840.150/tahun pada skala III. Kontribusi pendapatan usaha ternak kambing terhadap pendapatan keluarga petani peternak terbesar adalah pada skala III sebesar 39,9\%, sedangkan kontribusi pendapatan usaha ternak kambing terhadap pendapatan keluarga petani peternak pada skala I dan II adalah sebesar 31,4\% dan 36,7\% dimana data dapat dilihat pada Tabel 3. Berdasarkan hasil penelitian menunjukan bahwa peternakan kambing di kecamatan Rasau Jaya Kabupaten Kubu Raya merupakan peternakan sebagai cabang usaha bukan sebagai pekerjaan utama. Tribudi dan Ridwan (2017) menyatakan peternakan dapat di kelompokkan menjadi empat kelompok, yaitu: 1) peternakan sebagai usaha sambilan, yaitu petani mengusahakan komoditas pertanian terutama tanaman pangan, sedangkan ternak hanya sebagai usaha sambilan untuk mencukupi kebutuhan rumah tangga (subsisten) dengan tingkat pendapatan usaha dari peternakan < 30\%. 2) peternakan sebagai cabang usaha, yaitu peternak 
mengusahakan pertanian campuran dengan ternak dan tingkat pendapatan dari usahaternak mencapai 30-70\%. 3) peternakan sebagai usaha pokok, yaitu peternak mengusahakan ternak sebagai usaha pokok dengan tingkat pendapatan berkisar antara 70$100 \%$, dan 4) peternakan sebagai industry dengan mengusahakan ternak secara khusus (specialized farming) dan tingkat pendapatan dari usaha peternakan mencapai $100 \%$. Skala peternakan di Indonesia umumnya peternakan rakyat berskala kecil dan tingkat usaha masih tradisional yang belum dilandasi orientasi ekonomi

\section{Kesimpulan}

Berdasarkan hasil penelitian dapat disimpulkan bahwa rata-rata pendapatan usaha ternak kambing adalah Rp. 6.500.350/tahun pada skala I, Rp 8.634.210/tahun pada skala II dan Rp 10.840.150/tahun pada skala III.. Kontribusi usaha ternak kambing terhadap pendapatan keluarga peternak pada ketiga skala adalah 31,4\% pada skala I, 36,7\% pada skala II dan 39,9\% pada skala III yang menggambarkan bahwa usaha ternak kambing di Kecamatan Rasau Jaya Kabupaten Kubu Raya merupakan usaha sampingan dan belum bisa dikatakan sebagai usaha utama.

\section{DAFTAR PUSTAKA}

Budiarsana, I.G.M., I.K. Sutama., R. Dharsana., U. Adiati., Hastono., M.S. Hidayat, Mulyawan, Bachtiar dan R. Sukmana., 2001. Siklus Berahi dan Fertilitas Kambing Peranakan Ettawa pada Perkawinan Alami dan Inseminasi Buatan. Penelitian Ternak Ruminansia Kecil. Balai Penelitian Ternak. Pusat Penelitian dan Pengembangan Peternakan. Badan Penelitian dan Pengembangan Pertanian Bogor. Bogor

Chamdi, C.A. 2002. Study of Sosio Economics Profile of Small Holder Goat Farming in Gumelar Sub-District, Banyumas Regency. J. Animal Production 6(2) : 61-67.

Garantjang, S., 2004. Pertumbuhan Anak Kambing Kacang pada Berbagai Umur Induk yang Dipelihara Secara Tradisional. Jurnal Sains dan Teknologi. April 2004. Vol 4 no 1: 40-45.

Martawidjaya, M. 1992. Barn Design for Smallruminant Production. Dalam: P. Ludgate and S. Scholz (Eds). New Technologies for Small Ruminant Production in Indonesia. SRCSRP and Riap Publ., Winrok International Institute for Agricultural Development. Morriton-Arkansas

Rusdiana, S. dan Praharani. 2009. Profil dan Analisis Uasaha Swapi Perah di Kecamatan Cepogo Kabupaten Boyolali. Seminar Nasional: Peningkatan Daya Saing Agribisnis Berorientasi Kesejahteraan Petani.

Soetriono, 2003. Pengantar Ilmu Pertanian. Bayumedia. Jember. 
Jurnal Sains Peternakan

Vol 7 No 1, Juni 2019, 22-28

ISSN 2579-4450

Tribudi, Y. A dan M.R. Ristyawan. 2017. Analisis Ekonomi Sapi Potong Pola Gaduhan: Studi Kasus di Desa Slorok, Kecamatan Kromengan, Kabupaten Malang. Jurnal Ekonomi Bisnis dan Kewirausahaan2017, Vol. 6, No. 1, 27-42

Wina, E dan B. Tangendaja., 2000. Pemanfaatan Kaliandra (Calliandra calothyrsus) Sebagai Hijauan Pakan Ruminansia Di Indonesia. Disampaikan dalam Lokakarya Produksi Benih dan Pemanfaatan Kaliandra. Balai Penelitian Ternak Bogor. Bogor. 